1 Favaloro, R. G., et al., fournal of Thoracic and Cardiovascular Surgery, 1967, 54, 359.

2 Johnson, W. D., Flemma, R. J., and Lepley, D. Jnr., Annals of Thoracic

Surgery, 1970, 9, 436.
Grondin, C. M., et al., Circulation, 1971, 44, 815.

Grondin, C. M., et al., Circulation, 1971, 44, 815.

5 Arderman, E. L., et al., New England Journal of Medicine, 1973, 288, 535.

- Wright, J. S., et al., Medical fournal of Australia, 1974, 1, 57.

British Medical fournal, 1972, 2, 603.

Gott, V. L.) American fournal of Cardiology, 1974, 33, 431.

- Anderson, R. P., et al., Annals of Thoracic Surgery, 1972, 63, 353

10 Cooley, D. A., et al., Annals of Thoracic Surgery, 1974, 17, 211.

11 Balcon, R., et al., British Heart Fournal, 1974, 36, 841.

13 Oberman, A., et al., Bulletin of the New York Academy of Medicine, 1972,

48, 1109 .
14 Bruschke, A. V. G., Proudfit, W. L., and Sones, F. M., Circulation, 1973, $47,1147$.

15 Ross, R. S., et al., Medical fournal of Australia, suppl. No. 1, 2, 6.

Proudfit, W. L., Shirey, E. K., and Sones, F. M., Circulation, 1966, 33, 901

${ }^{7}$ Amsterdam, E. A., Wolfson, S., and Gorlin, R., American fournal of Cardiology, 1969, 23, 104.

18 Cohen, M. V., et al., Circulation Supplements, 1972, 45-46, No. 1, p. 57 19 Gotsman, M. S., Lewis, B. S., and Bakst, A., South African Medical fournal, 1973, 47, 641 .

20 Mobert, C. H., Webster, J. S., and Sones, F. M., American fournal of Cardiology, 1972, 29, 282.

${ }^{21}$ Lichtlen, P. R., and Moccetti, T., Circulation Supplements, 1972, 45-46, Nos. 2-7.

${ }_{22}^{2}$ Walker, J. A., et al., Circulation Supplements, 1972, 45-46, No. 1, p. 86. 23 Hallin, R. W., et al., American fournal of Surgery, 1971, 122, 164.

24 Bourassa, M. G., et al., Circulation Supplements, 1972, 45-46, No. 1, p. 79. 25 Bemis, C. E., et al., Circulation, 1973, 47, 455.

26 Rees, G., et al., New England fournal of Medicine, 1971, 284, 1116.

27 Chatterjee, K., et al., New England fournal of Medicine, 1972, 286, 1117.

${ }^{28}$ Friedberg, C. K., Circulation, 1972, 45, 727.

29 Bousvaros, G., Chandry, M. A., and Piracha, A. R., American fournal of Cardiology, 1972, 29, 255.

30 Downs, A. R., and Morrow, I. M., Surgery, 1972, 72, 699.

${ }_{31}$ Lewis, B. S., and Gotsman, M. S., Thorax, 1974, 29, 209.

${ }_{32}$ British Medical fournal, 1973, 3, 601.

\section{Night Terrors}

The night terror (pavor nocturnus or incubus) is perhaps the most fearful of human experiences yet it is transient and leaves little lasting memory. It afflicts most children at some time and occasionally adults too. Attacks occur mainly in the first hour or two of sleep. A few strangled words or cries precede bloodcurdling shrieks; the child sits up and stares wide-eyed. He may stumble out of bed or by movement, words, and expression reveal how he would seek to avoid some horror. Oblivious of his parents and of their soothing words he does not see their own alarmed faces. Within minutes he is again sleeping soundly and in the morning remembers nothing untoward.

Where night terrors have lately become much more frequent a relation to day-time anxiety can usually be seen-a recent stay in hospital by the child, 1 absence from home of the mother, a change of house, a new school, the death of a grandparent or school-friend, a fire in a neighbour's house, a marital crisis between the parents, or, in the case of adults, a recent motor accident or wartime battle experience. Yet it must be emphasised that night terrors occur also in those in whom there is no evidence of neurotic disorder by day. ${ }^{23}$ They will occur in epileptic as in non-epileptic children, as will enuresis or sleep-walking; but like these latter, and notwithstanding the explosive drama, night terrors are not epileptic phenomena. ${ }^{4}$

In recent years Fisher et al. $^{5-7}$ have applied electrophysiological techniques and intensive post-terror questioning to many adult patients. The night terror differs from the nightmare in that it comes early in the night and arises from nonrapid eye movement sleep with large, slow electrical brain waves instead of from the rapid eye movement (R.E.M.) stage of sleep most closely associated with vivid dreaming. It is abrupt and is not a gradual development of a dream adventure; the heart rate rises not gradually over a minute or more but abruptly from perhaps 60 to 160 /minute in the space of 15 seconds, together with violent respirations. The deeper the sleep (to judge by the slowness of the E.E.G. waves) and the longer this deep sleep episode has just lasted the more severe the terror. Sometimes the anguished cries for help, the agonized cursings, seem to lead out of simpler mental life that questioning reveals was present just before the attack. Commonly the words betray fear of attack by persons or animals, fear of entrapment, fear of falling, dying, or of choking. Generally it seems as if the night terror is part and parcel of a spontaneous, natural arousal from deep sleep, such as occurs many times every night. Alertness and anxiety are commonly in parallel and drugs that diminish one usually diminish the other. Even though their brain mechanisms must be separate, in the night terror anxiety-arousal and wakefulness-arousal may be being activated together when they should not. Diazepam has been found effective for adult sufferers ${ }^{6}$ and imipramine has been advocated for children ${ }^{8}{ }^{9}$ but at such an age is best avoided.

The parents of the child suffer much distress, and it is they who should be reassured that no grave psychological abnormality or damage is signified, that the child will have no memory of his attacks, and that time will bring amelioration. Environmental stress in housing or family interplay can sometimes be pin-pointed, when the night terrors will provide an incentive for new solutions.

1 Levy, D., American fournal of Diseases of Children, 1945, 69, 7

2 Gastaut, H., and Broughton, R., Recent Advances in Biological Psychiatry,

${ }^{3}$ Mack, J. E., Nightmares and Human Conflict. Boston, Little, Brown and Company, 1970.

4 Tassinari, C. A., et al., Electroencephalography and Clinical Neurophysiology, 1972, 33, 503 .

5 Fisher, C., et al., fournal of the American Psychoanalytic Association, 1970, $18,747$.

7 Fisher, C., et al., Archives of General Psychiatry, 1973, 28, 252.

8 Pesikoff, ${ }^{\circ}$ et al., Fournal of Nervous and Mental Disease, $1974,158,174$. 128, 778 .

- Tec, L., Fournal of the American Medical Association, 1974, 228, 978.

\section{Chemoprophylaxis against Tuberculosis}

The term chemoprophylaxis against tuberculosis has many shades of meaning. It has been used to describe prophylaxis on a community-wide basis, ${ }^{12}$ so including both individuals already infected and those non-infected. More accurately, the term is given to the prevention of infection, sometimes called primary chemoprophylaxis. Disease or secondary prophylaxis describes the use of drugs to prevent disease in positive tuberculin reactors. Chemoprophylaxis has also been used to describe treatment intended to prevent relapse of apparently inactive, tuberculosis, either untreated or inadequately treated. Finally it is used to describe treatmentincreasingly advocated nowadays-in tuberculin positive reactors receiving prolonged therapy with high doses of steroids or with cytotoxic drugs.

Isoniazid is commonly used alone in antituberculosis chemoprophylaxis, because it is effective, cheap, acceptable, and has few side effects. Fears that isoniazid resistant organisms would emerge have proved unfounded, ${ }^{3}$ and with the discovery of several other effective antituberculosis drugs available in reserve there has been less reluctance to use isoniazid alone. The maximum daily dose of isoniazid is usually $300 \mathrm{mg}$ (or $10 \mathrm{mg} / \mathrm{kg}$ for children) given for one year. 
The only serious side effect is hepatitis, which has been infrequent; 4 the chance occurrence of endemic viral hepatitis probably accounts for some of the reported cases. In the United States Public Health Service trials of chemoprophylaxis given to contacts $^{5}$ isoniazid was stopped because of side effects in $1.9 \%$ of cases compared with $1.5 \%$ of those receiving a placebo.

Isoniazid prophylaxis against tuberculosis has reduced tuberculous disease in all controlled trials during the period of drug administration, and in most of them the protection has continued during subsequent years. ${ }^{5}$ In the American trials $^{5}$ in individuals with primary tuberculosis there was a reduction of subsequent tuberculosis morbidity, comparing isoniazid with a placebo, of $90 \%$ during the treatment year and $70 \%$ in later years: in contacts the reductions were $77 \%$ and $47 \%$ respectively.

Horwitz and Magnus ${ }^{2}$ have recently reported a 12-year follow-up of a community-wide controlled trial of isoniazid prophylaxis in Greenland. The dose of isoniazid in the trial was small; 6-7 mg/kg (average) was given on two consecutive days each week for three months and this regimen was repeated for a further three months after an intervening three months without treatment. The results showed a $30 \%$ reduction of tuberculosis in the isoniazid treated group during the first six years but no significant difference between treated and placebo groups in the seventh to twelfth years.

In the Greenland trial and another reported from Tunisia,9 where prophylaxis was less effective in preventing morbidity, it is likely that the dose prescribed or consumed or both may have been too small. A disappointing protection by isoniazid reported from Japan 7 may have been due to the much higher incidence of rapid inactivators of isoniazid in that country. The effectiveness of prophylaxis may also depend on racial susceptibility and the prevalence of tuberculosis. How frequently exogenous reinfection occurs is uncertain, but it might occur more readily in those who received isoniazid prophylaxis soon after infection, when the development of immunity may be impaired. ${ }^{8}$

It is reasonable to conclude that adequate isoniazid prophylaxis reduces subsequent tuberculous morbidity very appreciably in primary tuberculosis, in contacts (especially those with strong tuberculin sensitivity), and in those with presumed inactive disease. ${ }^{5}$

How may chemoprophylaxis best be employed in the United Kingdom ? Though tuberculous infection is probably declining at about $9 \%$ per year ${ }^{9}$ the B.C.G. programme is likely to remain economical and afford the best protection for tuberculinnegative reactors during the next decade. The B.C.G. programme, contact surveillance, and radiography will identify many who may benefit from chemoprophylaxis: those with tuberculin sensitivity, infected but not obviously diseased, and those with evidence of tuberculosis of doubtful activity. ${ }^{1011}$ The reduction of future infectious disease in known higherrisk groups such as immigrants, especially Asians, may merit special consideration. Since motivation is poor $^{12}$ on the part of both the patient and physician when treating a symptomless person, it seems wise to select very carefully those most likely to benefit from prophylaxis. Such a scheme might mean giving isoniazid alone to all children under 12 years found to have tuberculin sensitivity of Heaf grades $2^{\circ}, 3^{\circ}$, and $4^{\circ}$ but with no other evidence of disease: the age limit might be extended, say to 18 , for immigrants and natives with $3^{\circ}$ and $4^{\circ}$ positive Heaf grades. Those with evidence of apparently inactive radiological disease, including many now being followed at chest clinics, might do better with closely supervised treatment for 6-12 months with isoniazid plus rifampicin or ethambutol, followed by discharge. 1 Comstock, G. W., Ferebee, S. H., and Hammes, L. M., American Review
of Respiratory Diseases, 1967, 95, 935.

${ }^{2}$ Horwitz, O., and Magnus, K., American fournal of Epidemiology, 1974,

${ }^{3}$ Ferebee, S. H., Bulletin of the International Union Against Tuberculosis, $1968,41,161$.

${ }^{4}$ Dubin, I. N., et al., American Review of Respiratory Diseases, 1971, 104,

5 Ferebee, S. H., Advances in Tuberculosis Research, 1970, 17, 28.

Nyboe, J., Farah, A. R., and Christensen, O. W., W.H.O. Tuberculosis Technical Information (circular), April 1963.

${ }_{7}$ Bush, O. B., et al., American Review of Respiratory Diseases, 1965, 92, 732.

8 Houk, V. N., et al., Archives of Environmental Health, 1968, 16, 46.

9 Springett, V. H., Tubercle, 1971, 52, 136.

10 Horwitz, O., American fournal of Epidemiology, 1973, 97, 148.

11 Grzybowski, S., et al., American Review of Respiratory Diseases, 1971,

12 Khoury, S. A., Theodore, A., and Platte, V. J., American Review of
. The Respiratory Diseases, 1969, 99, 345.

\section{Medical Management of Heartburn}

Though heartburn results from irritation of the oesophagus by acid refluxing from the stomach, it is not always relieved simply by taking antacids. The corollary is also true: reflux may occur without causing symptoms. Recently developed techniques for measuring intraoesophageal pressures and $\mathrm{pH}$ have disclosed the complex nature of oesophageal function, ${ }^{1}$ especially at its lower end, and they also provide clinicians with a tool for assessing the value of different forms of treatment.

Swallowing is associated with the passage down the oesophagus of peristaltic waves. These cause a sudden fall in pressure (relaxation) at the oesophageal sphincter, followed by rapid contraction once the wave has passed. Whereas resting pressure in the oesophagus itself is around atmospheric, sphincter tone is normally maintained at a pressure of $10-40 \mathrm{~mm} \mathrm{Hg}$. In patients with reflux it is generally much lower. Pressure changes in the body of the oesophagus are mediated predominantly by cholinergic nerves, while sphincter tone is largely maintained by the interaction of polypeptides such as gastrin, secretin, and prostaglandins, released as the result of $\mathrm{pH}$ changes in stomach and duodenum. Active sphincteric responses, however, are dependent on nervous mechanisms, since cholinergic impulses and stimulation of $\alpha$-receptors cause contraction while stimulation of $\beta$-receptors results in relaxation.

Armed with this information the physician has a rational basis for the advice which he gives. Thus, alkalies should be effective not only because of local neutralization of acid but because they might improve sphincter tone by stimulating release of gastrin. But when symptoms are severe they need to be given initially at hourly intervals, and preparations which can be chewed or sucked are probably best. With modern formulation there is little danger of alkalosis. Choice of drug is usually a matter of individual preference rather than being based on any objective evidence of superiority. In recent years there has been a tendency to combine the antacid with substances having other properties considered desirable, for example, local anaesthetics, silicones, and alginates. The last have recently been shown to be effective in reducing acid $\mathrm{pH}$ in the oesophagus, ${ }^{2}$ but rather surprisingly its associated antacid alone was no more successful than a placebo. There is a need for further work along these lines to compare not only different protective compounds but also different antacids. 